Received 20.03.2016 Reviewed 10.07.2016 Accepted $\quad 02.08 .2016$

A - study design

B - data collection

C - statistical analysis

D - data interpretation

E - manuscript preparation

F - literature search

\section{Hydrological modelling of wadi Ressoul watershed, Algeria, by HEC-HMS model}

\author{
Imene Diabi SKHAKHFA $^{\text {ABCDEF }}$, Lahbaci OUERDACHI ${ }^{\text {AF }}$
}

Laboratory of Hydraulics and Hydraulic Constructions, Badji Mokhtar-Annaba University, P.O. BOX 12, 23000 Annaba, Algeria; e-mail: imene.232000@gmail.com,ouerdach@univ-annaba.org

For citation: Skhakhfa I.D., Ouerdachi L. 2016. Hydrological modelling of wadi Ressoul watershed, Algeria, by HECHMS model. Journal of Water and Land Development. No. 31 p. 139-147. DOI: 10.1515/jwld-2016-0045.

\begin{abstract}
This study presents a flood estimation model for wadi Ressoul in El Berda watershed, north east of Algeria. To ensure the overall consistency of simulated results, it is necessary to develop a validation process, particularly in regions where data are scarce or limited and unreliable. To this we must calibrate and validate the model over the hydrograph as measured at the output. Calibration and validation processes were carried out using different sets of data (CN, SCS Lag and Muskingum K). Evaluation on the performance of the developed flood model derived using HEC-HMS (hydrologic modelling system) yield a correlation coefficient $R^{2}$ close to 1 and the Nash-Sutcliffe efficiency. We limit ourselves to modelling flood of short duration for which the process of evapotranspiration is negligible. Several events have been tested, including two to calibrate and one to validate the model. So it can be said that using the HEC-HMS model had the highest efficiency in with the values of these parameters calibrated, based on objective functions (percent error in peaks), with 8.8 percent difference between of observed and simulated discharges with $R^{2}$ value is 0.87 and the Nash-Sutcliffe efficiency value is 0.99 .
\end{abstract}

Key words: Annaba, calibration, flood modelling, HEC-HMS, validation

\section{INTRODUCTION}

The term watershed applies to a naturally occurring hydrologic unit that contributes storm runoff to a single waterway classified on the basis of its geographical area [AIS, LUS 1990]. Shortage of water in most of the water scare region is not only caused by low or unpredictable rainfall pattern but also due to the lack of capacity to conserve and manage the available rainwater in a sustainable manner (IbrahimBathis and Ahmed). Some of the water scare arid and semi-arid watersheds in Algeria where rainfall patterns are unpredictable, subject to undergo various hydrological constraints. Surface runoff estimation based on rainfall is one of the prerequisites for planning and execution of water resource projects [MAJIDI, SHAHEDI 2012; MANOHARAN, MURUGAPPAN 2012; MASOUD 2015]. The ability of rainwater har- vesting is of vital importance to sustain agriculture and other economic activities in drought-prone areas of arid and semi-arid regions [KEBLOUTI et al. 2015].

The advantage of using the Geographic Information System (GIS) in hydrological management has been clearly stated by many researchers [JAYAKRISHNAN et al. 2005; MARTIN et al. 2005; REINELT et al. 1991]. Efforts have also been made to integrate some hydrological models with the GIS environment. Most of these models are physically-based distributed models, e.g. HEC-HMS, SWAT, TOPMODEL, and WEPP. This integration allows assessment and prediction of the impact of watershed management practices [ARNOLD et al. 1998; VERMA et al. 2010; WHEATER et al. 1999; ZHANG et al. 2008]. The present research tries to study the efficiency of HEC-HMS model in wadi Ressoul. 


\section{MATERIALS AND METHODS}

\section{STUDY AREA}

Wadi Ressoul watershed is located at Annaba in northeast part of Algeria Fig. 1). The total area of wadi Ressoul drainage network is around $105.85 \mathrm{~km}^{2}$, the altitude area varies from 55 and $925 \mathrm{~m}$ which lying between $7^{\circ} 27^{\prime} 40.81^{\prime \prime}$ to $7^{\circ} 36^{\prime} 56.24^{\prime \prime}$ E longitude and $36^{\circ} 32^{\prime} 55.13^{\prime \prime}$ to $36^{\circ} 41^{\prime} 19.4^{\prime \prime} \mathrm{N}$ latitude from the study area for the present work.

For this study, rainfall and runoff of three events (9.23.2009 to 9.25.2009, 11.2.2010 to 11.4 .2010 and 3.15.2011 to 3.16.2011) at Ain El Berda stream flow gauging and rainfall station was taken as the outlet of the watershed which is located at $7^{\circ} 36^{\prime} 19^{\prime \prime}$ E longitude and $36^{\circ} 41^{\prime} 4.34^{\prime \prime} \mathrm{N}$ latitude and has elevation of
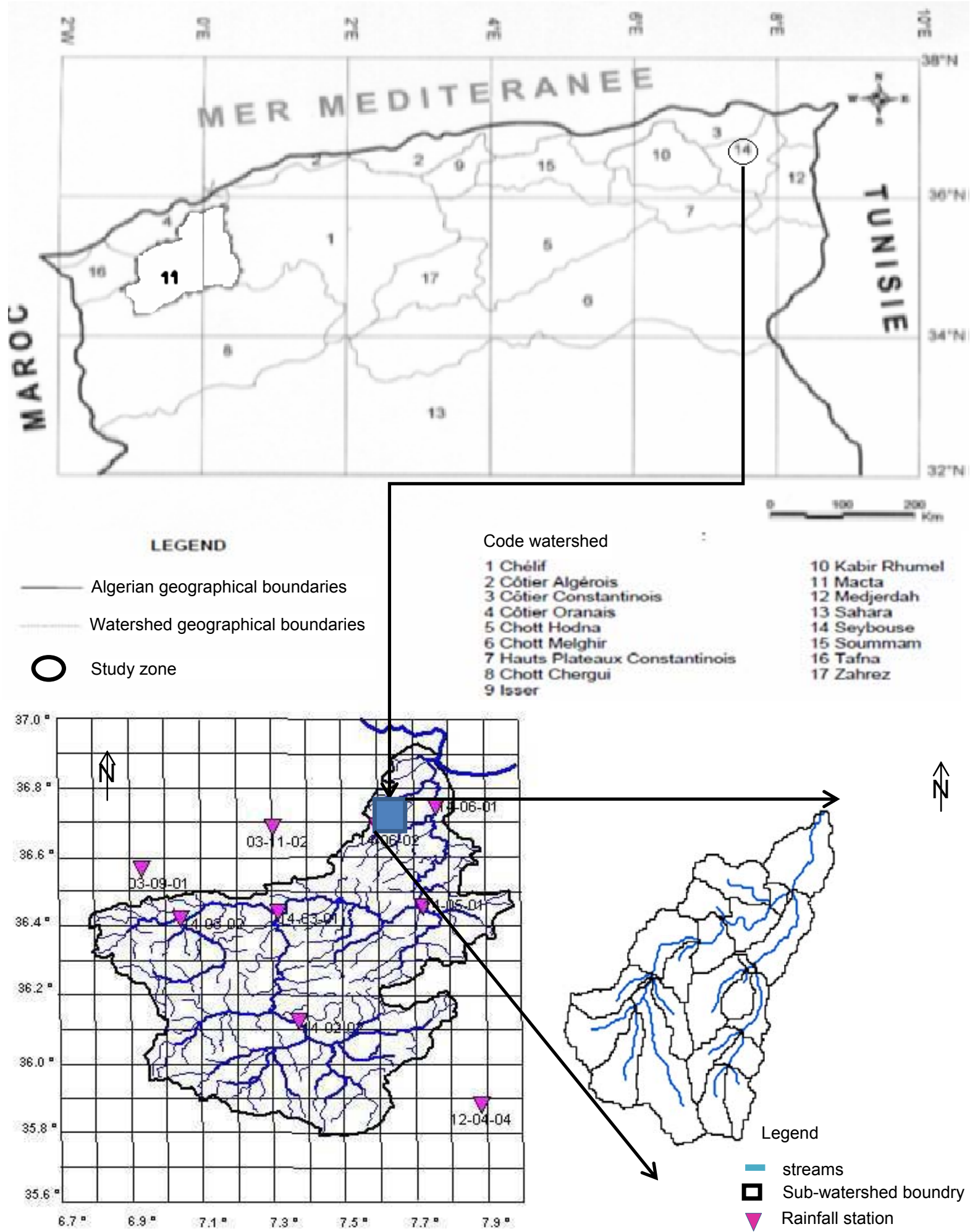

Fig. 1. Location map of wadi Ressoul watershed with sub-watersheds; source: own elaboration 
$55 \mathrm{~m}$ a.s.l. were obtained from National Agency of Water Resources (ANRH). The type of climate in the study area is Mediterranean type where the annual of precipitations is $660 \mathrm{~m}$ and the mean annual of relative humidity is about $75 \%$ while the minimum and maximum seasonal temperatures are $7^{\circ}$ and $45^{\circ}$ respectively.

\section{DESCRIPTION OF THE HYDROLOGIC MODEL}

HEC-HMS is a physically based, semi-distributed hydrologic model developed by the US Army Corps of Engineers to simulate the hydrologic response of a watershed subject to a given hydrometeorological input [SCHARFFENBER et al. 2010]. The model uses underlying DEM information to partition the basin into sub-watersheds. The size of the sub-watershed is determined a priori by the modeller, and few or no guidelines are available for sub-watershed selection.

In most cases, the balance between the resolution of the distributed information and the computation time required for simulation is the main factor considered for this selection.

The model can simulate individual storm events as well as continuous precipitation input at minute, hourly, or daily time steps [ZHANG et al. 2013].

\section{Parameters in HEC-HMS}

The HEC-HMS offers a variety of model options to simulate runoff production, at the hillslope scale and flow channels. These include SCS (Soil Conservation Service) curve number, SCS unit hydrograph, and baseflow estimation methods which are necessary to calculate water losses, runoff transformation, and baseflow rates. In our study, the Muskingum and constant loss method are used to calculate flood routing and water losses along the channel. The values of the model parameters have the potential to change along with changing sub-basin sizes. We provide a description of the governing equations and the physical meaning of model parameters for hillslope and channel processes here and will subsequently use them to analyse their behaviour as the size of the subwatersheds changes.

Hydrologic mechanisms on hillslope include losses due to ponding, infiltration, and baseflow production. The SCS loss model for basin loss is given by:

$$
P_{e}=\frac{\left(P-I_{a}\right)^{2}}{P-I_{a}+S}
$$

where $P_{e}=$ excess precipitation, $P=$ accumulated precipitation, $I_{a}=$ initial abstraction and can be initialized as $0.2 S, S=$ the potential maximum retention and is a function of curve number $(\mathrm{CN}): S=(25400-254$ $\mathrm{CN}) / \mathrm{CN}$ (SI system) [USACE 2000]. The initial abstraction and $\mathrm{CN}$ are required parameters.

The SCS unit hydrograph (UH) rainfall-runoff transformation model is a dimensionless unit hydro- graph $U_{t}$ expressed as a ratio to peak (RP) discharge $U_{P}$ for any fraction of time $t / T_{P}$, where $T_{P}$ is the time to peak. The peak discharge is given by $U_{P}=C A / T_{P}$, where $\mathrm{C}$ is the conversion constant (2.08 in $\mathrm{SI})$ and Ais the sub-watershed area. The time of peak $T_{P}$ is calculated as $T_{P}=\Delta t / 2+t_{P}$, where $\Delta t$ is the time step in HEC-HMS and $t_{P}$ is the time lag defined as the time difference between the centre of excess precipitation and the centre of UH [USACE 2000]. $t_{P}$ is a required input parameter.

The exponential recession model for baseflow is given by

$$
Q_{t}=Q_{0} k_{t}
$$

where $Q_{0}=$ initial baseflow, $k=$ an exponential decay constant. During the recession period of a flood event, a RP is specified to derive the threshold flow at which the baseflow is calculated as a fraction of peak flow. $Q_{0}, k$ and the RP are required parameters.

Hydrologic mechanisms in the transport in the channel contain Muskingum parameters and constant channel loss. The Muskingum method for channel routing is chosen. In this method $x$ and $K$ parameters must be evaluated. Theoretically, $K$ parameter is time of passing of a wave in reach length and $x$ parameter is constant coefficient. Therefore parameters can be estimated with the help of observed inflow and outflow hydrographs. Parameter $K$ estimated as the interval between similar points on the inflow and outflow hydrographs. Once $K$ is estimated, $x$ can be estimated by trial and error [USACE 2000].

The Muskingum model is frequently used for flood routing in natural channels [CHU, CHANG 2009]. The continuity and storage equation in mathematical terms is expressed as

$$
\frac{d W}{d t}=I-Q ; W=[x I+(1-x) Q]
$$

where $W=$ channel storage; $I$ and $Q=$ inflow and outflow rates, respectively; $K=$ storage time for a channel and is estimated as $K=L / V_{m}$, where $L=$ channel length and $V_{m}=$ flow wave velocity; $x=$ a weighting factor varying from 0 to 0.5 that can be estimated as. $\frac{1}{2}\left(1-\frac{Q_{0}}{B S_{0} V_{m} L}\right) \cdot Q_{0}=$ the reference flow, $B=$ the top width of flow area, $S_{0}=$ the friction slope [CUNGE 1969]. $K$ and $x$ are required parameters. Water loss through channels is approximated by a constant channel loss method. The two critical parameters in this model are the constant flow rate subtracted and the ratio that is remaining.

\section{MODEL CALIBRATION AND ASSESSMENT}

The initial step in model calibration is a manual adjustment of model parameters using the trial-and-error method, which enables the modeler to make a subjective adjustment of parameters that gives an 
appropriate fit between observed and simulated hydrographs [ZHANG et al. 2013].

\section{Model evaluation statistics (standard regression)}

Pearson's correlation coefficient $(r)$ and coefficient of determination $\left(R^{2}\right)$ : Pearson's correlation coefficient $(r)$ and coefficient of determination $\left(R^{2}\right)$ describe the degree of collinearity between simulated and measured data [MORIASI et al. 2007]. The correlation coefficient, which ranges from -1 to 1 , is an index of the degree of linear relationship between observed and simulated data. If $r=0$, no linear relationship exists. If $r=1$ or -1 , a perfect positive or negative linear relationship exists. Similarly, $R^{2}$ describes the proportion of the variance in measured data explained by the model. $R^{2}$ ranges from 0 to 1 , with higher values indicating less error variance, and typically values greater than 0.5 are considered acceptable [SANTHI et al. 2001; VAN LIEW et al. 2003]. Although $r$ and $R^{2}$ have been widely used for model evaluation, these statistics are oversensitive to high extreme values (outliers) and insensitive to additive and proportional differences between model predictions and measured data [LEGATES, MCCABE 1999].

The value of $R^{2}$ is calculated using the following equation:

$$
R^{2}=\left[\frac{\sum_{i=1}^{n}\left(Q_{o}-\bar{Q}_{o}\right)_{i}\left(Q_{s}-\bar{Q}_{s}\right)}{\sqrt{\sum_{i-1}^{n}\left(Q_{o}-\bar{Q}_{o}\right)^{2}} \sqrt{\sum_{i-1}^{n}\left(Q_{s}-\bar{Q}_{s}\right)_{i}^{2}}}\right]^{2}
$$

where: $Q_{o}=$ observed discharge, $Q_{s}=$ simulated discharge, $n=$ total number of observed data

\section{Model evaluation statistics (dimensionless)}

The calibrated model performance was evaluated using the Nash-Sutcliffe model efficiency (NS)
[NASH, SUTCLIFFE 1970; MiaO et al. 2013]. The NS is used to assess the agreement between observations and simulations. Mathematically, it is expressed as

$$
N S=1-\frac{\sum_{i=1}^{n}\left(Q_{o}-\bar{Q}_{s}\right)_{i}^{2}}{\sum_{i=1}^{n}\left(Q_{o}-\bar{Q}_{o}\right)_{i}^{2}}
$$

where: $Q_{o}=$ observed discharge, $Q_{o}=$ average observed discharge, $Q_{s}=$ simulated discharge; all $Q$ variables have the unit runoff volume per time step (e.g. $\left.\mathrm{m}^{3} \cdot \mathrm{s}^{-1}\right)$. Nash-Sutcliffe efficiencies can range from $\infty$ to 1 . An efficiency of $1(\mathrm{NS}=1)$ corresponds to a perfect match between the modelled and observed time series, whereas an efficiency of $0(\mathrm{NS}=0)$ indicates that the model predictions are as accurate as the mean of the observed data. If the efficiency is less than $0(\mathrm{NS}<0)$, the observed mean is a better predictor than the model. More detailed information on NS can be found in papers by: LEGATES and MCCABE [1999], MCCUEN et al. [2006], SCHAEFLI and GUPTA [2007] and KASHID et al. [2010].

\section{DATA AQUISITION}

The data used in this study were: map Ain Berda $\mathrm{N}^{\circ} 33$ and map Guelma $\mathrm{N}^{\circ} 54$ on 1/50.000 scale and Digital Elevation Model (DEM) was aquired from the CGIAR Consortium for Spatial Information. All data are georectified and projected to Geographic Coordinate System-World Geographic System 1984 (GCS WGS) Universal Transverse Mercator (UTM) zone32 North (Fig. 2) for delineate watershed, sub-watershed and generate the stream networke (Fig. 3) with Geospatial Hydrologic Modeling Extension (HEC-GeoHMS) along with ArcHydro extention in Arcgis 9.3 utilised to create the input file for use HEC-HMS.
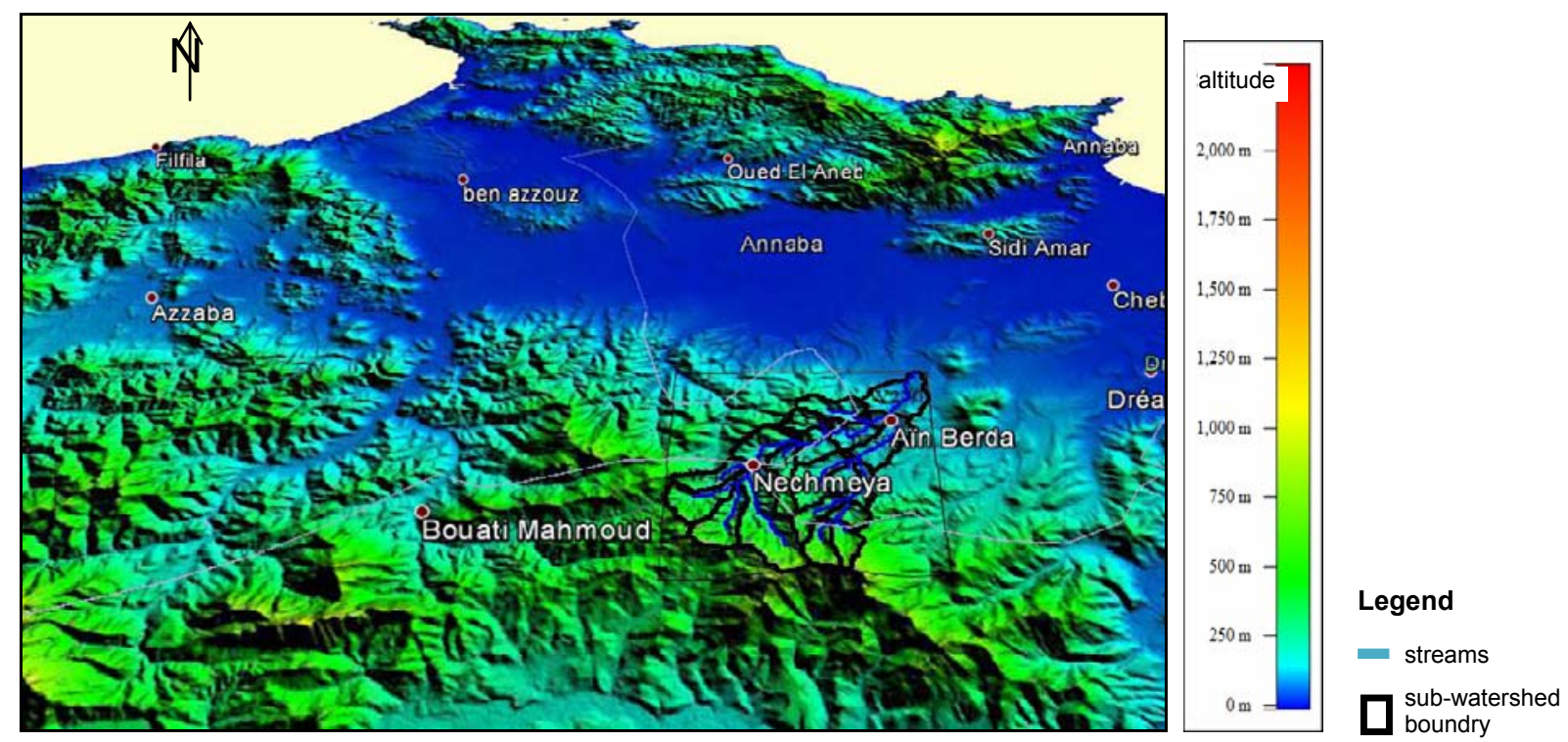

Fig. 2. Delineate watershed, sub-watershed and generate the stream network from DEM; source: own elaboration based on CGIAR Consortium for Spatial Information 


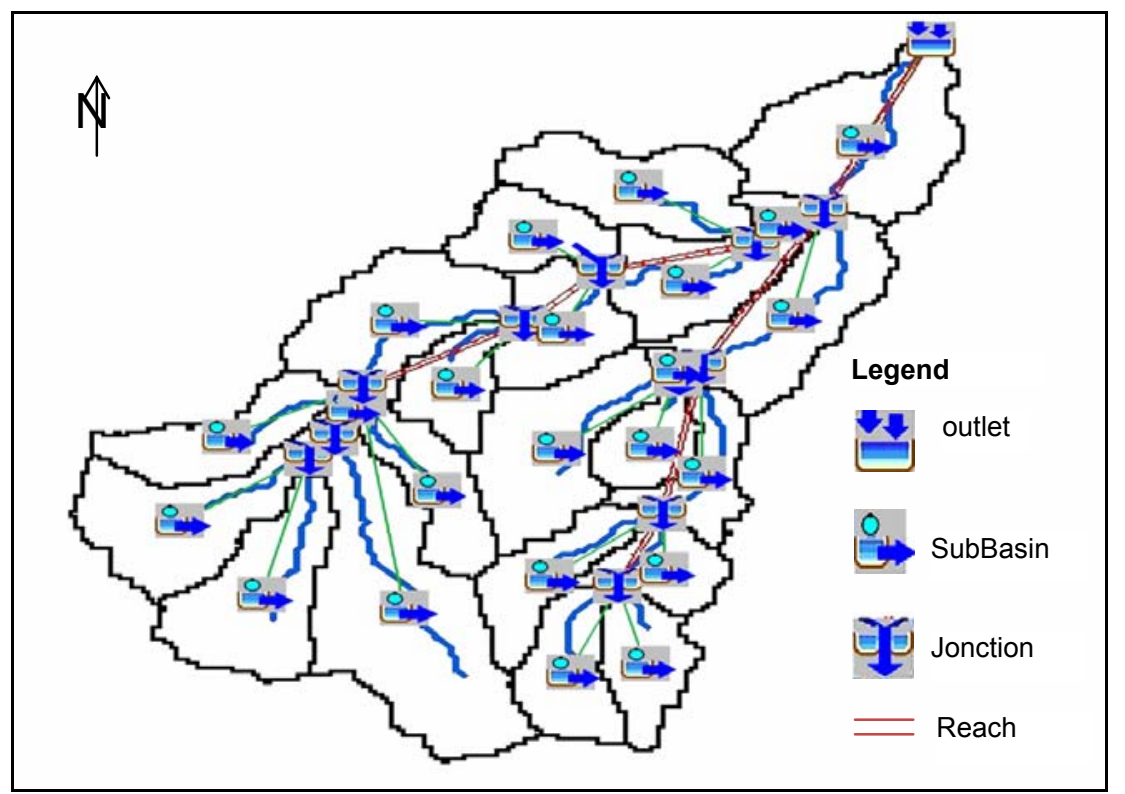

Fig. 3. Schematic diagram of wadi Ressoul watershed as HEC-HMS input; source: own elaboration

\section{BASIN MODEL}

In the present study, the basin model was created using the HEC-GeoHMS and then imported into the HEC-HMS with all its hydrologic elements: 23 subcatchments, 12 junctions, 12 reaches and a sink used to represent the outlet of a basin (node with inflow and without outflow) (Fig. 3).

\section{RESULTS AND DISCUSSION}

\section{MODEL CALIBRATION AND VALIDATION}

The successful application of the hydrologic watershed model depends upon how well the model is calibrated which in turn depends on the technical capability of the hydrological model as well as the quality of the input data. HEC-HMS watershed model is calibrated for the event based simulation. The ob- jective of the model calibration is to match observed simulated runoff volumes, runoff peaks and timing of hydrographs with the observed ones.

In the present study, a combination of manual and automated calibration techniques was used. Automated calibration, known as "trial optimization" in HEC-HMS, was used to obtain optimum parameter values that give the best fit between observed and simulated flow volume values [RUELLAND et al. 2008].

The hydrological model results showed a reasonable fit between simulated and observation hydrograph shape. Figures 4 and 5 a time-series comparison of simulate and observed streams flow for the outlet of watershed for the calibration periods 23-25 September 2009 and 15-16 March 2011 (we limit ourselves to modeling flood of short duration for which the process of evapotranspiration is negligible). The peak values of measured flow match well with

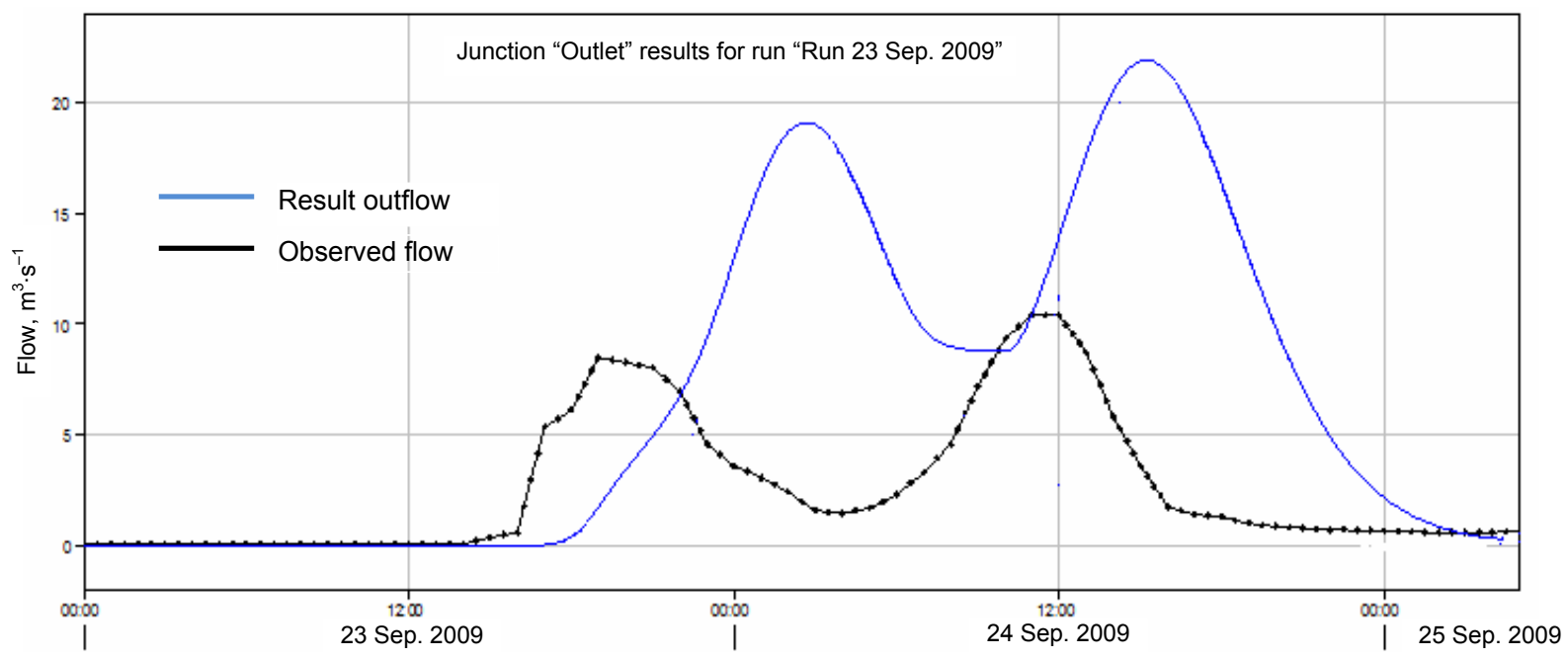

Fig. 4. Observed and simulated stream flow hydrographs for the calibration (23-25 September 2009) period; source: own study 


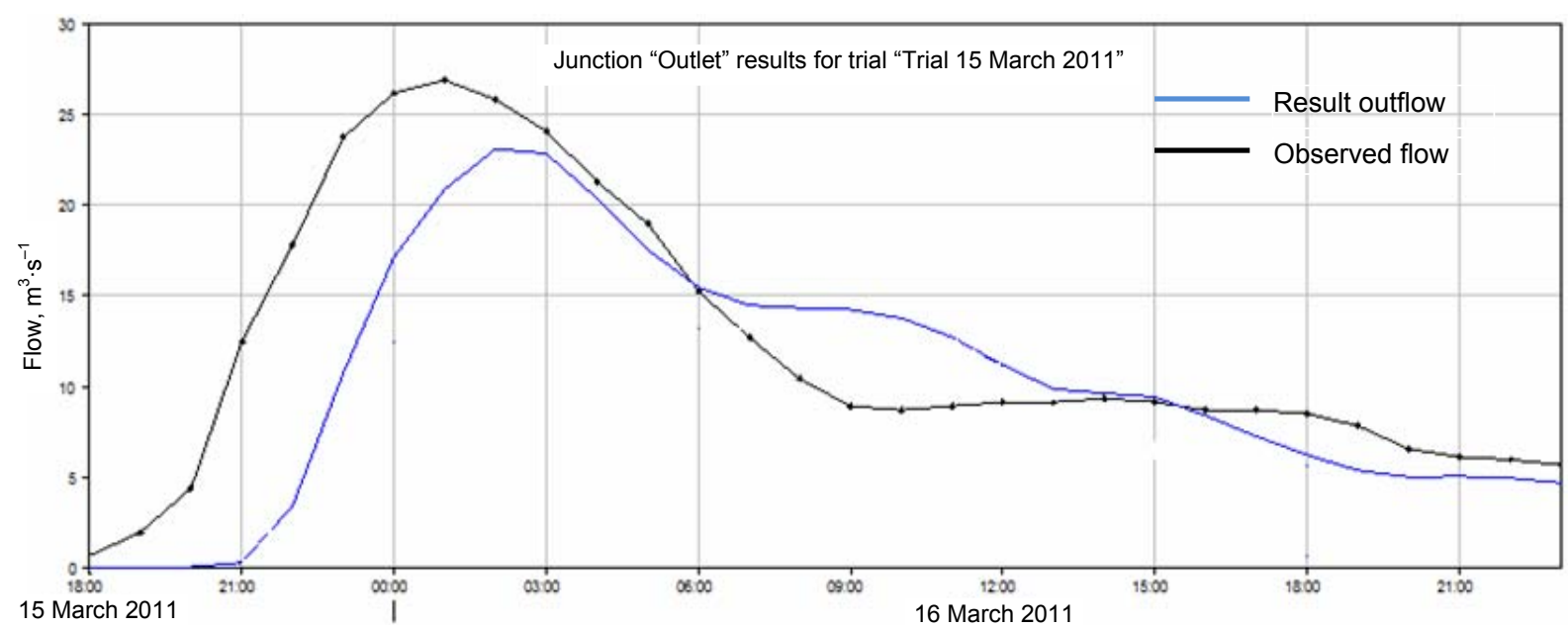

Fig. 5. Observed and simulated stream flow hydrographs for the calibration (15-16 March 2011) period; source: own study

the peak values of the simulated flow, although the model tended to overestimate runoff as observed though stream measurements.

After calibration of the model, we notice a greatly decreasing of peak discharge compared before calibration. Calibrated values of the HEC-HMS parameters for the calibration period are presented in Table 1 and 2 .

Table 1. Calibrated values of the model parameters (SCS Lag and $\mathrm{CN}$ )

\begin{tabular}{|l|r|r|c|c|}
\hline \multirow{2}{*}{$\begin{array}{c}\text { Subbasin } \\
\text { ID }\end{array}$} & \multicolumn{2}{|c|}{ SCS Lag (min) } & \multicolumn{2}{c|}{ CN } \\
\cline { 2 - 5 } & original & calibrated & original & calibrated \\
\hline W270 & 176.8 & 193.7 & 80.5 & 99.0 \\
\hline W280 & 114.1 & 114.1 & 77.7 & 77.7 \\
\hline W290 & 49.7 & 62.2 & 83.7 & 99.0 \\
\hline W300 & 158.9 & 169.1 & 84.5 & 81.6 \\
\hline W310 & 98.2 & 98.2 & 81.2 & 81.2 \\
\hline W320 & 66.4 & 66.4 & 85.0 & 85.0 \\
\hline W330 & 90.1 & 90.1 & 84.0 & 840 \\
\hline W340 & 112.3 & 112.3 & 79.5 & 79.5 \\
\hline W350 & 92.5 & 92.5 & 81.2 & 81.2 \\
\hline W360 & 53.3 & 53.3 & 85.2 & 85.2 \\
\hline W370 & 95.6 & 95.6 & 89.9 & 89.9 \\
\hline W380 & 117.3 & 98.8 & 83.1 & 99.0 \\
\hline W390 & 87.6 & 87.6 & 83.9 & 83.9 \\
\hline W400 & 104.7 & 84.2 & 84.0 & 77.5 \\
\hline W410 & 55.8 & 55.1 & 82.1 & 75.7 \\
\hline W430 & 87.9 & 70.8 & 83.2 & 76.8 \\
\hline W450 & 134.3 & 109.3 & 85.2 & 59.3 \\
\hline W460 & 104.1 & 86.0 & 83.0 & 72.1 \\
\hline W470 & 95.5 & 61.6 & 85.0 & 69.4 \\
\hline W480 & 115.0 & 95.1 & 73.0 & 67.3 \\
\hline W490 & 76.4 & 62.9 & 78.0 & 71.9 \\
\hline W500 & 58.1 & 57.4 & 86.0 & 79.3 \\
\hline W510 & 60.6 & 60.4 & 86.0 & 79.3 \\
\hline
\end{tabular}

Explanations: SCS = Soil Conservation Service, $\mathrm{CN}=$ curve number. Source: own elaboration.
Table 2. Calibrated values of the model parameters (Muskingum $K$ )

\begin{tabular}{|l|c|c|}
\hline \multirow{2}{*}{ Channel ID } & \multicolumn{2}{|c|}{ Muskingum $K, \mathrm{~h}$} \\
\cline { 2 - 3 } & original values & calibrated values \\
\hline Reach-1 & 2.39 & 2.45 \\
\hline Reach-10 & 0.33 & 0.50 \\
\hline Reach-11 & 1.65 & 12.59 \\
\hline Reach-12 & 0.19 & 0.04 \\
\hline Reach-2 & 0.67 & 0.68 \\
\hline Reach-3 & 1.90 & 1.94 \\
\hline Reach-4 & 1.02 & 1.04 \\
\hline Reach-5 & 2.44 & 0.48 \\
\hline Reach-6 & 0.22 & 0.06 \\
\hline Reach-7 & 1.85 & 1.89 \\
\hline Reach-8 & 0.13 & 0.20 \\
\hline Reach-9 & 0.50 & 0.76 \\
\hline
\end{tabular}

Source: own elaboration.

The calibrate model was then used to estimate a stream flow wadi Ressoul watershed using precipitation period 2-4 November 2010. The observed and simulated hydrographs before and after validation have been shown in Figures 6 and 7.

\section{MODEL EVALUATION}

Model performance is assessed using two performance indicators, namely the NS and $R^{2}$, who have the values 0.867 and 0.99 respectively.

The correlation coefficient indicates the accuracy of a model. The value of one indicates perfect prediction [RAZI et al. 2010]. Graph of simulated versus observed flows before and after the validation (2-4 November 2010) period are shown in Figures 8 and 9. 
Junction "Outlet" results for run "Run 2 November 2010"

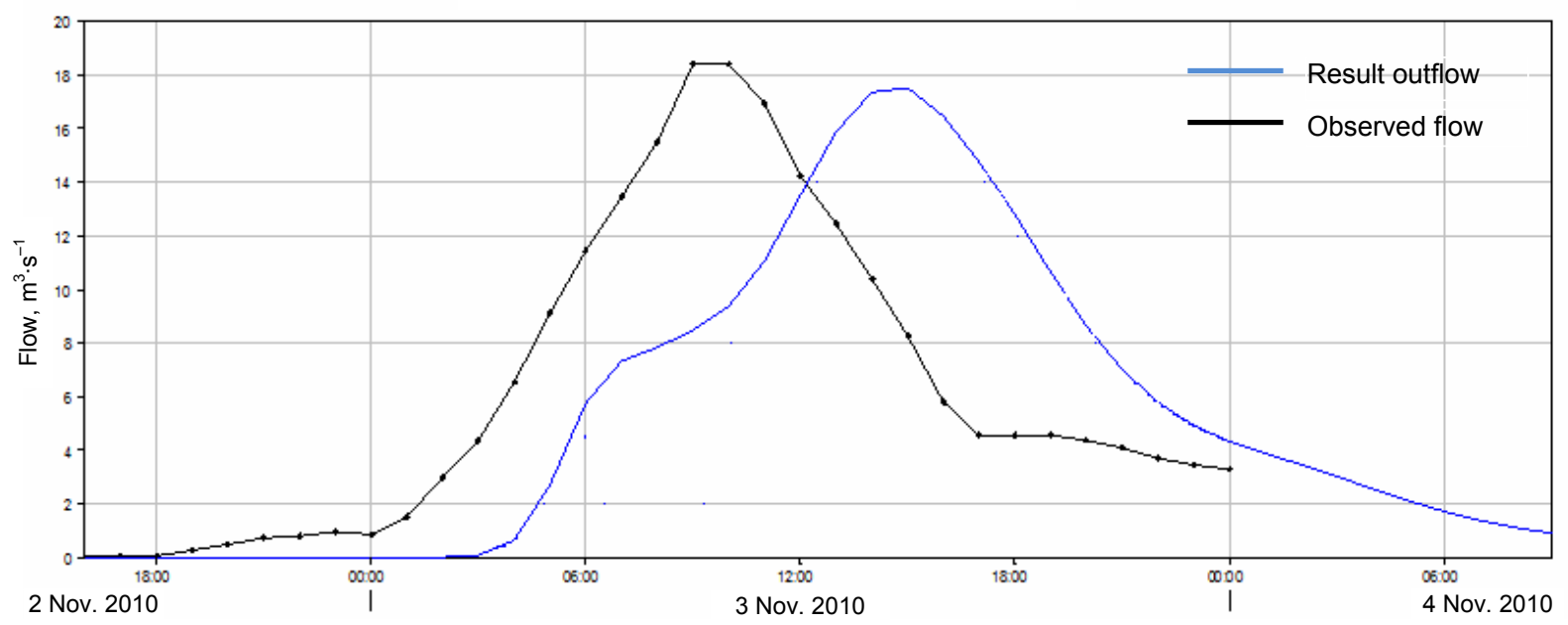

Fig. 6. Observed and simulated streamflow hydrographs before the validation (2-4 November 2010) period; source: own study

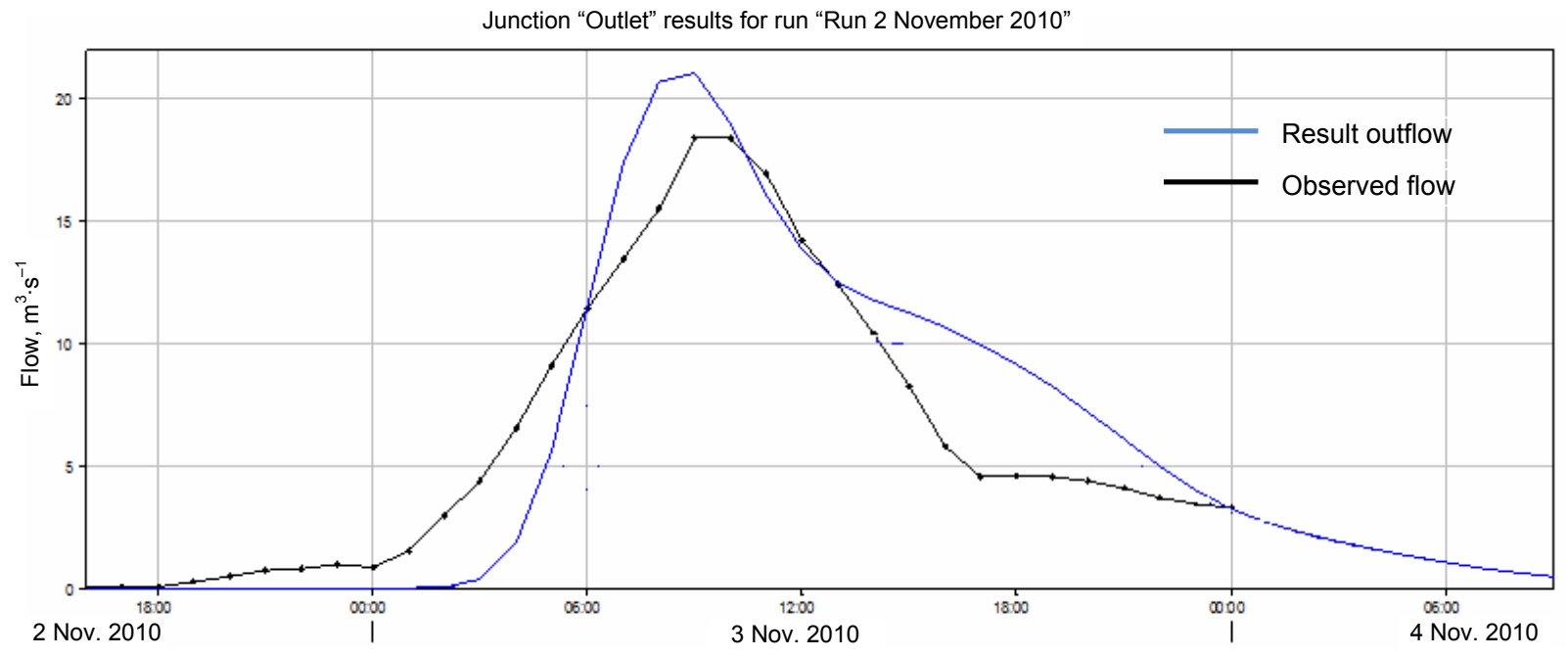

Fig. 7. Observed and simulated streamflow hydrographs after the validation (2-4 November 2010) period; source: own study

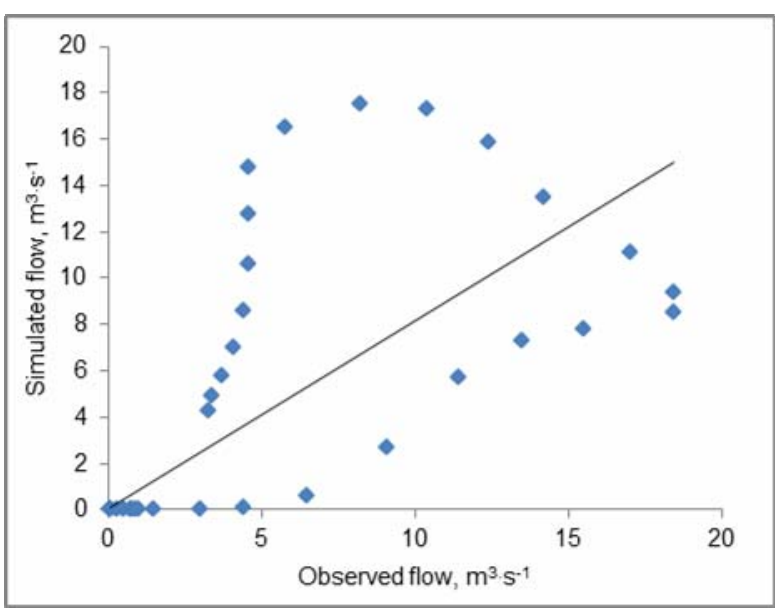

Fig. 8. Graph of simulated versus observed flows before the validation (2-4 November 2010) period; source: own study

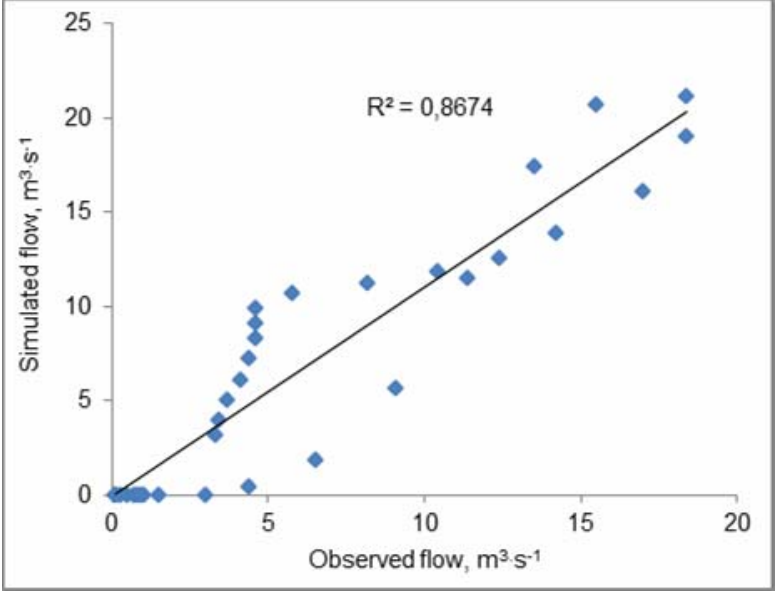

Fig. 9. Graph of simulated versus observed flows after the validation (2-4 November 2010) period; source: own study 


\section{CONCLUSION}

Runoff estimation is mandatory to sustain the water resources but in this region the monitored data are limited. The present research tries to study the efficiency of HEC-HMS model in wadi Ressoul. A sensitivity analysis was carried out by adjusting different parameter values in both the HEC-HMS for watershed. After running the models repeatedly, the simulated streamflow results were compared with monitored values in outlet of basin (where the discharge station is located) at each change of parameters. In this regard, the Curve Number, SCS Lag and Muskingum $K$ parameters are calibrated for two events of raining and flooding, one event for validate model. The results of the measuring approved the results of the model and showed that the difference between the peak discharge observed and validated model was about 8.86 percent with $R^{2}$ value is 0.867 and Nash-Sutcliffe efficiency is at 0.99 . The present study concludes that the model can be utilised for the wadi Ressoul.

\section{REFERENCES}

AIS, LUS 1990. Watershed atlas of India. Soil and Land Use Survey of India. Department of Agriculture and Cooperation. Ministry of Agriculture. IARI Campus, New Delhi.

ARnOld J.G., SRINIVASAN R., MUtTIAH R.S., Williams J.R. 1998. Large area hydrologic modeling and assessment Part 1: model development. Journal of the American Water Resources Association. Vol. 34. Iss. 1 p. 73-89.

Chu H.J., Chang L.C. 2009. Applying Particle Swarm Optimization to Parameter Estimation of the Nonlinear Muskingum Model. Journal of Hydrologic Engineering. Vol. 14. Iss. 9 p. 1024-1027.

Cunge J.A. 1969. On the subject of a flood propagation computation method (Muskingum Method). Journal of Hydraulic Research. Vol. 7. Iss. 2 p. 205-230.

IBRAHIM-BATHIS K., AHMED S.A. 2016. Rainfall-runoff modelling of Doddahalla watershed - an application of HEC-HMS and SCN-CN in ungauged agricultural watershed. Arabian Journal of Geosciences. Vol. 9 p. 116. DOI: $10.1007 / \mathrm{s} 12517-015-2228-2$.

JAYAKRISHNAN R., SRINIVASAN R., SANTHI C., ARNOLD J.G. 2005. Advances in the application of the SWAT model for water resources management. Hydrological Processes. Vol. 19. Iss. 3 p. 749-762.

KASHID S.S., GHOSH S., MAITY R. 2010. Streamflow prediction using multi-site rainfall obtained from hydroclimatic teleconnection. Journal of Hydrology. Vol. 395. Iss. 3 p. 23-38.

Keblouti M., Ouerdachi L., Berhail S. 2015. The use of weather radar for rainfall runoff modeling, case of Seybouse watershed (Algeria). Arabian Journal of Geosciences. Vol. 8 p. 1-11. DOI: 10.1007/s12517-0131224-7.

Legates D.R., McCABE G.J. 1999. Evaluating the use of "goodness-of-fit" measures in hydrologic and hydroclimatic model validation. Water Resources Research. Vol. 35. Iss. 1 p. 233-241.

MAJIDI A., SHAHEDI K. 2012. Simulation of rainfall-runoff process using Green-Ampt method and HEC-HMS model (Case study: Abnama Watershed, Iran). International Journal of Hydraulic Engineering. Vol. 1. Iss. 1 p. 5-9.

Manoharan A., Murugappan A. 2012. Estimation of runoff in an ungauged rural watershed, Tamil Nadu State, India. International Journal of Engineering Science and Technology. Vol. 4. Iss. 2 p. 449-456.

Martin P.H., LeBoeuf E.J., Dobbins J.P., Daniel E.B., ABKOwITZ M.D. 2005. Interfacing GIS with water resource models: a state-of-the-art review. Journal of the American Water Resources Association. Vol. 41. Iss. 6 p. 1471-1487.

MASOUD M. 2015. Rainfall-runoff modeling of ungauged wadis in arid environments (case study wadi Rabigh Saudi Arabia). Arabian Journal of Geosciences. Vol. 8 p. 2587-2606. DOI: 10.1007/s12517-014-1404-0.

McCuen R.H., Knight Z., CutTer A.G. 2006. Evaluation of the Nash-Sutcliffe efficiency index. Journal of Hydrologic Engineering. Vol. 11. Iss. 6 p. 597-602.

MiaO C.Y., DuAN Q.Y., Sun Q.H., Li J.D. 2013. Evaluation and application of Bayesian multi-model estimation in temperature simulations. Progress in Physical Geography. Vol. 37 p. 727-744. DOI: 10.1177/030913331349 4961.

Moriasi D.N., ARnold J.G., VAn Liew M.W., Bingner R.L., HARMel R.D., VEITH T.L. 2007. Model evaluation guidelines for systematic quantification of accuracy in watershed simulations. Transactions of the ASABE. Vol. 50. Iss. 3 p. 885-900.

NASH J.E., SutCliffe J.V. 1970. River flow forecasting through conceptual models: Part 1. A discussion of principles. Journal of Hydrology. Vol. 10. Iss. 3 p. $282-$ 290.

PedRAM E., RASHIDI M. 2014. Studying the efficiency of HEC-HMS models in simulating the flood of the Kordan stream. Advances in Natural and Applied Sciences. Vol. 8. Iss. 5 p. 463-468.

RAZI M.A.M. ARIFFIN J., TAHIR W., ARISH N.A.M. 2010. Flood estimation studies using Hydrologic Modelling System (HEC-HMS) for Johor River, Malaysia. Journal of Applied Sciences. Vol. 10. No. 11 p. 930-939.

Reinelt L.E., VeliKanje J., Bell E.J. 1991. Development and application of a geographic information-system for wetland watershed analysis. Computers, Environment and Urban Systems. Vol. 15. Iss. 4 p. 239-251.

Ruelland D., Ardoin-Bardin S., Billen G., Servat E. 2008. Sensitivity of a lumped and semi-distributed hydrological model to several methods of rainfall interpolation on a large basin in West Africa. Journal of Hydrology. Vol. 361. Iss. 1-2 p. 96-117.

Santhi C., ARnold J.G., Williams J.R., Dugas W.A., SRINIVASAN R., HAUCK L.M. 2001. Validation of the SWAT model on a large river basin with point and nonpoint sources. Journal of the American Water Resources Association. Vol. 37. Iss. 5 p. 1169-1188.

SCharffenber W., Ely P., DAly S., Fleming M., PAK J. 2010. Hydrologic modeling system (HEC-HMS): Physically-based simulation components [online]. 2nd Joint Federal Interagency Conference, Las Vegas, NV, June 27-July 1, 2010. [Access 20.02.2016]. Available at: http://acwi.gov/sos/pubs/2ndJFIC/Contents/4F_ Scharffenberg_02_24_10.pdf

SChaEFLi B., GUPTA H.V. 2007. Do Nash values have value? Hydrological Processes. Vol. 21. Iss. 15 p. 20752080. DOI:10.1002/hyp.6825

USACE 2000. Hydrologic Modeling System HEC-HMS. Technical Reference Manual. Davis CA pp. 149. 
VAn Liew M.W., ARNold J.G., GARBReCht J.D. 2003. Hydrologic simulation on agricultural watersheds: Choosing between two models. Transactions of ASAE. Vol. 46. Iss. 6 p. 1539-1551.

Verma A.K., Jha M.K., Mahana R.K. 2010. Evaluation of HEC-HMS and WEPP for simulating watershed runoff using remote sensing and geographical information system. Paddy Water Environ. Vol. 8. Iss. 2 p. 131-144. DOI: $10.1007 / \mathrm{s} 10333-009-0192-8$.

WAŁĘGA A. 2013. Application of HEC-HMS programme for the reconstruction of a flood event in an uncontrolled basin. Journal of Water and Land Development. No. 18 p. $13-20$.

Wheater H.S., Jolley T.J., OnOF C., Mackay N., ChanDLER R.E. 1999. Analysis of aggregation and disaggregation effects for grid-based hydrological models and the development of improved precipitation disaggregation procedures for GCMs. Hydrology and Earth System Sciences. Vol. 3. Iss. 1 p. 95-108. DOI: 10.5194/hess-395-1999.

Zhang H.L., WANG Y.J., WANG Y.Q., Li D.X., WANG X.K. 2013. The effect of watershed scale on HEC-HMS calibrated parameters: A case study in the Clear Creek watershed in Iowa, US. Hydrology and Earth System Sciences. Vol. 17. Iss. 7 p. 2735-2745.

Zhang X.S., Srinivasan R., Debele B., Hao F.H. 2008. Runoff simulation of the headwaters of the Yellow River using the SWAT model with three snowmelt algorithms. Journal of the American Water Resources Association. Vol. 44. Iss. 1 p. 48-61. DOI: $10.1111 /$ j.17521688.2007.00137.x.

\section{Imene Diabi SKHAKHFA, Lahbaci OUERDACHI}

\section{Hydrologiczne modelowanie zlewni rzeki Ressoul w Algierii za pomocą modelu HEC-HMS}

\section{STRESZCZENIE}

W publikacji przedstawiono model oceny powodzi opracowany dla rzeki Rassoul w zlewni El Berda w północno-wschodniej Algierii. Aby zapewnić spójność wyników symulacji, należy przeprowadzić proces sprawdzenia modelu, szczególnie w odniesieniu do regionów, w których dane są skąpe lub ograniczone i mało wiarygodne. W tym celu należało kalibrować model i dokonać jego potwierdzenia na podstawie danych hydrograficznych. Procesy kalibracji i testowania przeprowadzono z użyciem różnych zestawów danych (CN, SCS Lag i Muskingum K). W wyniku oceny zachowania skonstruowanego modelu HEC-HMS uzyskano współczynnik determinacji $R^{2}$ bliski 1 i dobry współczynnik efektywności Nasha-Sutcliffa. Autorzy ograniczyli się do modelowania powodzi o krótkim czasie trwania, gdy można pominąć ewapotranspirację. Testowano kilka zdarzeń, w tym dwa w celu kalibracji i jedno w celu potwierdzenia modelu. Można stwierdzić, że model HEC-HMS ma najwyższą wydajność opartą na obiektywnych funkcjach (procent błędu w szczytach fali) wyrażoną 8,8-procentową różnicą między obserwowanym i symulowanym odpływem, gdy $R^{2}=0,87$ i wartość współczynnika efektywności Nasha-Sutcliffa wynosi 0,99.

Slowa kluczowe: Annaba, HEC-HMS, kalibracja, modelowanie powodzi, testowanie 